stirred in the absence of organisms remained stable, and addition of gelatin to cultures as a protective colloid did not prevent destruction. When 0.01 per cent 'Thiomersalate' was added to the organisms destruction ceased immediately and culture filtrates of organisms were not active in destroying the enzyme. It seems, therefore, that it was the organisms which were destroying the enzyme and it is of interest to note that this phenomenon may explain the fact that Duthie and Haughton found only small amounts of coagulase when they attempted production by submerged culture.

We thank Dr. I. R. W. Lominski, Western Infirmary, Glasgow, for supplying Staphylococcus aureus $5 R$, and Mr. C. van Toller for assistance.

D. C. Edwards

G. H. TURNER

Biological Division,

Wellcome Research Laboratories, Beckenham, Kent.

${ }^{1}$ Linggood, F. V., Matthews, A. C., Pinfield, S., Pope, C. G., and Sharland, T.' R., Nature, 176, 1128 (1955).

Duthie, E. S., and Haughton, G., Biochem. J., 70, 125 (1958).

Chain, E. B., Paladino, S., Callow, D. S., Ugolini, F., and Van Der Sluis, J., Bull. World Health Org., 6, 73 (1952).

‘ Davies, G. E., J. Gen. Microbiol., 5, 687 (1951).

${ }^{5}$ Fahlberg, W. J., and Marston, J., J. Infect. Dis., 106, 111 (1960).

- Smith, D. D., Morrison, R. B., and Lominski, I., J. Path Bact., 64 567 (1952).

'Smith, D. D., Nature, 178, 1060 (1956).

- Rammelkamp, jun., C. H., Badger, G. F., Dingle, J. H., Feller, A. E., and Hodges, R. G., J. Infect. Dis., 86, 159 (1950).

- Ramon, G., Pochon, J., and Amoureux, G., C.R. Soc. Biol., Paris, 135,1502 (1941).

\section{Malignolipin and Malignant Tumours}

KosAkI et al. ${ }^{1-3}$ have recently reported the isolation of a new specific phospholipid, malignolipin, from malignant human and experimental tumours. They have described its role as a promoter of carcinogenesis ${ }^{4}$ and have claimed to have evolved a histological test for the identification of malignolipin ${ }^{5}$ and a diagnostic test for cancer ${ }^{6,7}$ based on the detection of this phospholipid in blood. Anti-malignolipin sera have been reported ${ }^{8}$ to reduce the viability of Yoshida sarcoma cells in vitro. These results await confirmation from other laboratories. The following therefore represents an attempt at isolating malignolipin from malignant tumours.

The material used in the work reported here comprised two types of human tumours (human tumours were kindly supplied by Dr. M. V. Sirsat, Pathology Department, Tata Memorial Hospital, Bombay)-breast and œesophagus carcinomas; three types of exporimental tumours-a transplantable mouse fibrosarcoma originally induced by Waravdekar and Randive ${ }^{\theta}$ and maintained in Swiss mice, spontaneous and transplantable breast tumours carried in $\mathrm{C} 3 \mathrm{H}(\mathrm{Jax})$ mice and a spontaneous reticulum cell sarcoma in golden hamsters; and normal mouse liver.

Each of the foregoing types of material was worked up in at least two separate experiments. The method of Kosaki et al. ${ }^{2}$ was carefully followed in all its details for the isolation of malignolipin picrate.

All tho solvents used for the extraction of malignolipin and the preparation of its picrate were previously purified by standard procedures. In each experiment, at least $12-15 \mathrm{~g}$ of the material were ground with 9 volumes of absolute ethanol. The alcohol extract was precipitated with acetone. The precipitate was filtered through a sintered glass funnel, dried and eluted with petroleum ether. This eluate was further precipitated with acetone, filtered through a sintered glass funnel, dried and finally eluted with benzene. The benzene extract was mixed with an equal volume of saturated solution of picric acid in benzene. The picrate formed was filtered through the sintered glass funnel, washed free of excess of picric acid with benzene and crystallized three times from dioxan benzene $(1: 7)$. It was finally erystallized from acetone.

A lemon-yellow picrate melting at $258^{\circ}-65^{\circ} \mathrm{C}$ was obtained from all the malignant tumours as well as from normal mouse liver. The mixed melting points of the picrate derived from these materials remained undepressed. The melting point of the picrate, how ever, was different from that quoted ${ }^{2}$ for malignolipin picrate $\left(123^{\circ} \mathrm{C}\right)$. Unlike the bluish-white fluorescence in the ultra-violet reported ${ }^{2}$ for the crystals of malignolipin picrate, this compound (m.p. $258^{\circ}-65^{\circ} \mathrm{C}$ ) does not exhibit any fluorescence in the ultra-violet either in the solid state or in solution. It is readily soluble in water, ethanol, acetone and dioxan but sparingly soluble in benzene, petroleum ether and chloroform. It did not show the presence of sulphur, halogens and phosphorus by Lassaigne's test ${ }^{10}$. Phosphorus could not be detected in any of the picrates even by Lowry's micromethod ${ }^{11}$. Analysis of the picrate shows C, 28.7 per cent, and $H, 2.5$ per cent by combustion method and N, 22.5 per cent by Johnson's method ${ }^{12}$.

Unidimensional ascending paper ehromatography of the picrates in butanol/pyridine water $(8: 2: 1)$ at $28^{\circ} \mathrm{C}$ yielded two spots with $R_{F}$ values $0.6(\mathrm{I})$ and $0 \cdot 26$ (II). Spot (I) was identified as picric acid from its $R_{F}$ value and absorption spectrum. It appears that the complex decomposed during chromatography. Similar decomposition of the picrates during chromatography has also been reported by other workers ${ }^{13,14}$. The spot (II) with $R_{F}$ value $0 \cdot 26$, when eluted with water, has no absorption in the visible range but has a $\lambda_{\max }$ at $256 \mathrm{~m} \mu$. The picrate has no absorption in the ultra-violet, but in the visible region it has an absorption maximum at $360 \mathrm{~m} \mu$ due to the picric acid part of the molecule.

In this investigation so far, I have been unable to isolate malignolipin picrate (m.p. $123^{\circ} \mathrm{C}$ ) from as many as five different types of pathologically confirmed malignant tumours listed above. Instead, a non-specific picrate has been obtained; its properties are much different from those reported for malignolipin picrate.

Department of Biochemistry,

\section{B. KaMAT*}

Indian Cancer Research Centre, Bombay 12, India.

* Present address: Department of Biological Chemistry, Harvard Medical School, Boston.

1 Kosaki, T., Ikoda, T., Kotani, Y., Nakagawa, S., and Saka, T., Science, 127, 1176 (1958).

'Kosaki, T., Nakagawa, S., and Saka, T., Mie Med. J., 10, 179 (1960).

${ }^{3}$ Kosaki, T., Nakagawa, S., and Saka, T., Proc. Jap. Acad., 36, 362 (1960).

4 Kosaki, T., and Nakagawa, S., Proc. Jap. Acad., 34, 297 (1958).

${ }^{5}$ Kosaki, T., and Saka, 'T., Proc. Jap. Acad., 34, 295 (1958).

- Kosaki, T., and Nakagawa, S., Proc. Jap. Acad., 34, 293 (1958).

7 Kosaki, T., Hasegawa, S., Uezumi, N., Fujimura, M., Saka, T. Kotani, Y., and Muraki, K., Mie Med. J., 10, 387 (1960).

8 Kosaki, T., Kotani, Y., Saka, T., and Nakagawa, S., Proc. Jap. Acad., 36, 527 (1960)

- Waravdekar, S. S., and Randive, K. J., J. Nat. Cancer Inst., 18, 555 (1957).

${ }^{10}$ Vogel, A. I., A Text Book of Practical Organic Chemistry, third ed., 1039 (Longmans, Green and Co., London and New York).

${ }_{11}$ Lowry, O. H., Roberts, N. R., Leiner, K. T., Wu, M. L., and Fars, A. L., J. Biol. Chem., 207, 1 (1954).

12 Johnson, M. J., J. Biol. Chem., 137, 375 (1941)

${ }_{13}$ Lugg, J. W. H., and Weller, R. A., Biochem. J., 42, 408 (1948),

14 Plattner, R. A., and Pfau, A. S., Helv. Chim. Aeta., 20, 224 (1937). 